ringe i Danmark. Forhåbentlig kan det foreliggende værk bidrage til at bedre på denne beklagelsesværdige situation.

Værket savner indeks. Og litteraturlisten har mærkeligt nok ikke $\mathrm{H}$. Noonans bog om Frege fra 2001 (som vist da udkom i december 2000) med, skønt der henvises til denne $\mathrm{i}$ indledningen (pp. 11 og 21). I øvrigt har man ikke ved kompilationen gjort sig den ulejlighed at opstøve tekster på dansk (eller nordisk) om Frege. Vi bliver præsenteret for pligtlisten. Denne er ganske rimelig, men har vel noget begrænset relevans for læsere af netop en oversættelse til dansk af Frege.

Lad mig imidlertid understrege, at der er tale om en højst tiltrængt og overordentlig anvendelig publikation. Måtte flere berige sig ved læsning af denne uforligneligt klarttænkende og banebrydende filosof! Forlag, redaktører, oversætter og indleder fortjener vore varmeste tanker. Det er i Freges ånd at offentliggøre $\mathrm{i}$ det mindste nogle af disse.

Stig Alstrup Rasmussen

\section{Det filosofiske liv}

\author{
Finn Thorbjorn Hansen, Det filosofiske liv, \\ Gyldendal 2002, 483 sider, 378 kr.
}

Det foreliggende værk er et forsøg på, som det hedder $\mathrm{i}$ indledningen, "at bygge bro mellem på den ene side idehistoriske og filosofiske indsigter og viden og på den anden side udvikling af pædagogisk teori og praksis." Den ene side, afhandlingens første del, består af læsninger af Foucault, Rorty, Kierkegaard og mange flere, hvilket ligesom de mange læsninger på den anden side, afhandlingens anden del, optager uforholdsmæssigt meget plads. Læsningerne af de tre filosoffer, som jeg har fremhævet, er stærke, men har en tendens til at gentage og variere det allerede sagte. Det skyldes, at bogen er diskuterende og skrider frem i modstillinger: han er enig i, men på den anden side uenig i..., det betyder ikke det og det, men snarere... I denne stil bliver alle indsigter bundet op på positioner - og det skal guderne vide, at denne bog præsenterer et sandt overflødighedshorn af standpunkter - og de gennemspilles igen og igen. Ofte knyttes forbindelserne hurtigt med et "jævnfør" eller "det er ligesom", hvilket ville være på sin plads, hvis det medførte en uddybning af begreberne. Men det er som om positionerne nogle gange er vigtigere end sagen, som jo var det filosofiske liv med tænkningen og dannelsen i centrum. Tag side $180 \mathrm{og}$ side 213, der hver indeholder mere 
end ti opremsninger af navne, hvilket skal hjælpe med til at introducere til de pågældende tænkere, men tænkningen begynder at gå i tomgang - med udsigt til endnu 250 siders navne-safari.

$\mathrm{Nu}$ skal det absolut hilses velkomment, at den filosofiske tænkning indsættes i den verden, hvor mennesket handler, elsker og lider med andre. Læsningerne af en række tænkere, der med en tænkningens lidenskab opholder sig på grænsen eller i bruddet, er som sagt virkeligt gode og peger frem imod afhandlingens anden del, som skal indføre læseren i den praktiske vejledning. Således forbindes den heroiske ironiker hos Foucault overbevisende med humoristen hos Kierkegaard. Begge giver deres liv stil eller lader sig digte igennem filosofiske praktikker, der bestandigt udlægger det filosoferende selv i nye eksperimenter. I Wittgensteins mere terapeutiske sprogbrug løser de filosofiske undersøgelser op for kramperne, eller med Arendt optør tænkningen de fastfrosne begreber. På den måde får forfatteren sagt en masse, og de mange identitetstegn bliver aldrig problematiseret, hvilket man kun kunne have noget at udsætte på, hvis afhandlingen sigtede imod en systematisk og kritisk analyse af den filosofiske tænkning. I indledningen gøres der præcis opmærksom på, at de idehistoriske indsigter skal gøres anvendelige i en større eksistentiel dannelseshorisont, og vil ikke selv blive underkastet en streng filosofisk undersøgelse.

Den bro imellem teori- og prak- sisafsnittet, som indledningsvis blev skitseret, slås imidlertid aldrig. I den anden del introduceres et hav af nye positioner, som ganske vist trækker på de positioner, der er blevet trukket op i den først del; men hvordan hænger alle begreberne om filosofisk etos, eros, praksis, selvomsorg, livsform, digtning sammen med vejledning, samtale, undervisning, metode? Skal det hele gå op i en højere enhed, så endemålet for den filosofiske vejledning er det filosofiske liv? Jeg mener, at overgangen imellem første og anden del udpeger et problem. Lige i begyndelsen af anden del introduceres Sokrates, som kun har været nævnt helt kort $\mathrm{i}$ forbindelse med tidligere læsninger, og det forudsættes bekendt, at "Først forlanger Sokrates, at hans samtalepartner vil samtale og ikke blot holde foredrag eller debattere. Samtalen skal være eksistentielt vedkommende for dem begge. Man må redeligt og ærligt fremlægge og samtale ud fra det, man virkelig selv mener, og han opfordrer til, at man taler i et dagligdagssprog, og ikke henviser til såkaldte autoriteter på området." Denne Sokrates findes nxppe i Platons dialoger, hvor Sokrates aldrig forlanger noget, der er ikke noget der skal være noget, og på hvilken måde står dagligdagssprog $\mathrm{i}$ modsætning til autoriteter? Sokrates - hos Platon velsagtens - opfordrer til at tale kort, men ikke nødvendigvis i dagligdagssprog, og jo, Sokrates beder gerne samtalepartneren om at henvise til sin læremester. Hvad 
bestiller denne Sokrates-figur her efter at læseren har kæmpet sig igennem 250 siders teori, hvor Sokrates i andre tænkeres sprog er blevet fremstillet som ironiker, som tænker, som etiker? Forfatteren tager nu fat på at introducere nye positioner, metoder og meget, meget mere, men hvordan metode og sandhed, vejledning og tænkning hænger sammen, det medreflekteres ikke i skriften selv. Skal denne tekstmasse blot vise hen til en konkret samtalesituation uden, at læseren i mødet med den foreliggende tekst bringes til tænkning, det eneste sted, hvor den, der er lidenskabeligt optaget af visdommen, kan ånde? En bog om livet $\mathrm{i}$ den filosofiske tænkning med forbilleder som Foucault, Kierkegaard, Wittgenstein og Arendt afvikler sin egen udsigelseskraft, hvis den blot vil introducere og beskrive. Jeg forlader bogen med håb om engang at møde forfatteren, så metodesnakken får en ende og tænkningen begynder.
Jonas Holst Sorensen

\section{Odysséen}

Homers Odyssé (+ledsager), oversat af Otto Steen Due, Gyldendal 2002, 463 sider, $495 \mathrm{kr}$.

Jeg kan hverken tro mine egne øjne eller ører efter at have været i selskab med Odysseus på hans lange færd over havet og på de græske øer. Læs den og læs den højt for hinanden, så Odysseus' bolig med bejlerne bænket omkring bordet træder synligt frem, så Telemachos, Penelope og Laertes i deres sorg får et menneskeligt ansigt $\mathrm{og}$ så Odysseus' møde med fristelserne og grusomhederne bliver stående tilbage på nethinden. Den kan med fordel læses i julemåneden, for med en sang hver dag nås alt $\mathrm{i}$ rette tid og lægger en dæmper på det kommercielle gavehysteri. Den kan læses af den eventyrlystne, der på grund af sygdom eller andre forhindringer ikke kan rejse, men som med Odysséen $i$ hånden har mulighed for at drage omkring $i$ en verden, hvor alle afstande vider sig ud og kun kan tilbagelægges ved at sætte det lange ben foran; den kan læses af en lærd forfatter, der finder på at lægge Odysséens handlingsgang ud i løbet af en dag, eller den kan læses af en halvstuderet røver, der mener, at hos Homer kommer alt for en dag; den kan læses af professoren, der ser begyndelsen på den vestlige civilisation $i$ det homeriske epos, eller af den skønne kvinde, der nok ved, hvor hun skal søge efter et rigtigt mandfolk. 